\title{
A Development Strategy for Afghanistan: Lessons of an Employment Policy Mission
}

\author{
I. Z. BHATTY and L. BEROUTI ${ }^{*}$
}

\begin{abstract}
This article has addressed itself to the delicate problem of evolving a development and employment strategy for a country still at its early stages of development and with traditional socio-economic structures. To modernise these structures and thus assist in achieving fuller and more productive employment, in reducing poverty and income inequality and in satisfying the basic needs of the mass of the population, the article based on the conclusions and recommendations of an ILO Mission has recommended a fourpronged attack: (1) a particular stress on rural development; (2) an urban strategy aiming at increasing the potential of the informal sector and at stimulating the rapid development of the industrial sector; (3) appropriate education, training and labour market policies; (4) finally, reforms in development planning and administration.
\end{abstract}

What is the road to development for a country like Afghanistan, which is predominantly rural and suffers from physical and socio-economic constraints to such an extent that it is ranged among the least developed countries? In particular, what strategy should be pursued if Afghanistan is to achieve fuller and more productive employment and reduce poverty and income inequality? To assist the Authorities in solving these problems, the ILO sent to this country, within the framework of the World Employment Programme, an Employment Policy Mission (April-May 1978).

This article summarises the Mission's major conclusions and recommendations. $^{1} \quad$ Its first part analyses the basic context which conditions all development efforts in Afghanistan: physical constraints, socio-economic structure and labour force patterns. The second part of the article presents the development strategy which was recommended by the Mission, concentrating on key sectors of the economy.

* The senior author is Deputy Director-General of the National Council of Applied Economic Research, India, and Chief of the Afghanistan Employment Policy Mission.

Mr. Berouti is associated with the International Labour Office, where he is responsible for the Organisation of the Afghanistan Mission.

The views expressed in this article are purely personal and do not represent the official opinions of the institutions with which the authors are associated.

${ }^{1}$ For a fuller account of the Mission's final report, see [5] . 


\section{BASIC PATTERNS}

Physical Factors

A basic feature of Afghanistan is its arid climate. Little rain/precipitation makes water a scarce resource, especially for irrigation. Together with topography, it explains the small proportion of cultivable land and vegetation. Any strategy for development and employment therefore has to tackle the crucial problem of the optimal use of water resources.

Another important aspect of Afghanistan is its land-locked character. The country's lack of direct access to the sea and its relative geographical isolation have limited in the past its access to foreign markets and slowed down its modernisation and development process. Since the latter is linked with the diversification of international economic relations, which is not contradictory but complementary to efforts towards more self-reliance, there is a definite need for reducing the country's isolation and increasing its commercial and employment potential through the expansion of its transport infrastructures, especially road and railway networks linking the capital, Kabul, to neighbouring countries and seaports. The optimal utilisation of these infrastructures also implies cooperative relations between countries of the region, including adequate arrangements concerning transit activities.

So far, only physical constraints were described. However, the review of physical factors affecting development would be incomplete without mentioning a major asset for the growth of the Afghan economy, viz. the availability of considerable reserves of mineral resources (natural gas, but also iron, copper, coal, oil, lead, zinc, etc.). A detailed survey of such resources and of their exploitation possibilities is called for.

\section{Economic Structure}

The economic structure of Afghanistan is typical of a country in its early stages of development. Indeed, available estimates of the Net Domestic Product, which is an indicator of the country's production patterns, show that traditional activities such as agriculture, animal husbandry, handicrafts and other rural non-agricultural activities contribute about four-fifths of this Product, while industry represents a very small part (details in Table 1). This raises the problem of modernisation: how to strengthen existing activities and improve their productivity and, at the same time, enhance the importance of the modern sector? As will be seen later, the Mission has attempted to bring satisfactory answers to this delicate question.

More specific problems arise in the main sectors of the economy. Thus, in agriculture, the crop-wise allocation of land reflects an orientation towards the satisfaction of basic needs: about 94 percent is devoted to food crops (mainly cereals, including wheat, but also fruits, vegetables and other products), while cotton is the major non-food item. However, production is very sensitive to weather fluctuations.
Table 1

Net Domestic Product and Employment in Afghanistan, 1975-1976

\begin{tabular}{lrrrr}
\hline & \multicolumn{2}{c}{ Net Domestic Product } & \multicolumn{2}{c}{ Employment } \\
\cline { 2 - 5 } Sectors & $\begin{array}{c}\text { In billions } \\
\text { of Afghanis }\end{array}$ & $\begin{array}{c}\text { As \% of } \\
\text { the total }\end{array}$ & $\begin{array}{c}\text { In } \\
\text { thousands }\end{array}$ & $\begin{array}{r}\text { As \% of } \\
\text { the total }\end{array}$ \\
\hline Agriculture, livestock & & & & \\
$\quad$ and allied activities & 53.81 & 55.4 & 2,871 & 67.8 \\
Mining & 0.10 & 0.1 & 5 & 0.1 \\
Handicrafts & 7.70 & 7.9 & 470 & 11.1 \\
Industry & 3.30 & 3.4 & 165 & 3.9 \\
Construction & 2.17 & 2.2 & 68 & 1.6 \\
Utilities & 0.82 & 0.8 & 14 & 0.3 \\
Trade and Commerce & 11.82 & 12.2 & 237 & 5.7 \\
Transport and & & & & 1.5 \\
$\quad$ communications & 3.46 & 3.6 & 62 & 8.0 \\
Other services & 13.91 & 14.3 & 340 & 100.0 \\
\hline & & & & \\
\hline
\end{tabular}

Source: World Bank and ILO Mission estimates.

${ }^{1}$ US dollar equalled 55.04 Afghanis in 1975-1976.

Besides, productivity is relatively low since, although the farmers are responsive to technological change (as evidenced by an increase in their use of fertilisers, improved seeds, etc.), the lack of secure irrigation facilities impedes a faster adoption of improved practices. The traditionally unequal distribution of land and water and the inequitable tenurial system also tend to discourage efforts to increase land productivity.

Livestock (mainly sheep and goats, but also cattle, donkeys, horses, camels and poultry) is the principal source of income for nearly two million nomads. Animal products mainly consist of milk, meat, wool and various kinds of skins. Animals are generally subject to high mortality and low productivity for various reasons: periodic failure of rainfall, frequent diseases and poor access of the nomads, who are on the move for a good part of the year, to public services (health, education, etc.). Besides, livestock development is threatened by practices of overgrazing and environmental degradation which are encouraged by inadequate transportation facilities and limited watering points. Finally, the nomads' contacts with the settled populations often raise delicate issues. All these problems will need to be remedied if an optimal utilisation of the Afghan livestock and grazing potential is to be achieved. 
Handicrafts represent about 8 percent of the Net Domestic Product, which is more than double the joint contribution of industry and mining. They are essentially household activities in which predominantly women and children are involved. Woollen carpets, rugs and, subsidiarily, leather products are the most important handicrafts, linked with a high export demand. It seems that major needs in this sector concern the provision of financing and marketing facilities, although in some cases technical assistance through elementary mechanisation and design improvements could be of considerable help.

In view of the country's natural resources, industry presents a strong development potential. However, basic policy issues will have to be resolved. A first prerequisite is a clear definition of the scope of the public sector as compared with the private sector. Ways to improve management in the former and to provide guidance to the latter will have to be determined. The extent to which stronger links could be established between large and small-scale industries, broadening the latter's market, should be explored. Upgrading facilities in terms of training and extension, credit and marketing assistance should be reviewed. Encouragements to the utilisation of appropriate technologies, taking into account the relative scarcity of capital, the size of the market and, also, the need for creating additional jobs, should be sought. Knowing that agro-based consumer goods constitute nearly one-half of all imports, prospects for import substitution should be examined. Last, but not the least, industrial expansion could be stimulated through gradual diversification of production and development of selected new industries, including export-oriented products. An integrated approach will have to be devised to tackle simultaneously all these problems.

Finally, foreign trade is characterised by the predominance of agricultural exports, natural gas being the principal non-agricultural export. Capital inflows, especially remittances from Afghans working abroad, also used to play an important role in the balance of payments. However, some limitations of this pattern have become evident: sensitiveness of agricultural exports to weather uncertainty and international fluctuations, accumulating foreign debt, and declining remittances in relation with developments in the region. To overcome these limitations and attain a more autonomous balance, the country needs to diversify its industrial production and exports, gear to this end selective capital aid and trade policies and harmonise with neighbouring countries migratory movements.

\section{Poverty and Income Inequality}

Economic problems are compounded by social constraints, in particular income inequality linked to land distribution and tenancy practices. In view of its stress on alleviating poverty and reducing inequalities, the ILO Mission has attempted to determine the extent and nature of these constraints.
The extent of poverty was estimated with reference to a poverty line corresponding to certain minimum requirements for food and non-food consumption (e.g. clothing, housing, etc.). The poverty line was defined in terms of the money value, at 1975-1976 prices, of an income which provides 2,150 calories per capita per day to all the population, and non-food consumption at (i) 20 percent of the total expenditure for the rural population and (ii) 30 percent of this expenditure for the urban population. This gives a per capita per year income of 2,600 Afghanis for the settled rural population and 3,460 Afghanis for the urban population.

Using the income distribution data available from various sample surveys, the proportions of the rural settled population falling below the poverty line were estimated as follows for 1970: 50 percent in the province of Nangarhar, 45 percent in Ghazni, 43 percent in Parwan, 37 percent in Laghman, 20 percent in Kunduz, 15 percent in Kandahar and 7 percent in Baghlan. ${ }^{2}$ Particularly affected by poverty were small tenants, landless labourers and other rural non-agricultural workers. The nomads are also believed to be, on the average, poorer than the rural settled population. As to the urban population, the proportions falling below the poverty line were estimated at 30 percent in Jalalabad, 26 percent in Pul-i-khumri, 25 percent in Kandahar, about 10 to 15 percent in Kabul and 9 percent in Lashkargah. ${ }^{3}$ A large proportion of them apparently belong to self-employed households engaged in a variety of "informal sector" activities. Along with these would be part of the wage workers. In spite of the wide regional and rural-urban variations in the proportions of the population falling below the poverty line, it is unlikely that the average proportion of the poor in Afghanistan's total population would be less than 30 percent. This is a relatively high proportion, which calls for a balanced rural-urban development strategy.

Based on the above income data, the ILO Mission has also derived for various provinces their Gini coefficients, which measure the extent of inequality in their income distribution: the closer these coefficients are to 1, the stronger is income inequality. The coefficients in 1970 ranged from 0.29 in Baghlan to 0.42 in Kunduz. ${ }^{4}$ Knowing the traditional socio-economic patterns in rural areas, one would have expected higher coefficients. Actually, available data for Kabul indicate a highly unequal income distribution, since in 1968-1969 nearly half (48 percent) of Kabul's population earned only 15 percent of the town's income, while 8 percent of its population earned more than 49 percent of that income. ${ }^{5}$ The resulting Gini coefficient $(0.53)$ shows that income distribution in the Capital was apparently more unequal than in the rural areas.

Income inequality in rural areas is itself linked to highly unequal land distribution. Indeed, in 1978, while the average size of land holdings was about 3 to 4 hectares, and a majority of them less than 2 hectares, some holdings went into

${ }_{3}^{2}$ ILO Mission estimates based on [2].

3ILO Mission estimates based on [3] and [6].

${ }_{5}^{4}$ ILO Mission estimates based on [2] . 
thousands of hectares. On the other hand, available data relating to Kandahar show that, in 1971 , the bottom 30 percent of rural housholds exploited only 2 percent of the total cultivated land, while the upper 10 percent of these households exploited 55 percent of that land.

Income and land inequalities were further aggravated by the inequitable and regressive character of the tenurial system. Not only the net income derived from the cultivation of a hectare was higher for owner-operators than for share-croppers and buzgars, ${ }^{6}$ but the gap between their shares tended to increase when new techniques and inputs (improved seeds, fertilisers, etc.) were introduced as a result of the availability of water for irrigation. ${ }^{7}$ For share-croppers, the larger share of productivity gains going to landowners could act as a disincentive to invest in improved inputs, especially in the face of weather uncertainties and insecurity of tenure. As to the buzgars, technological change could further expose them to eviction measures, since the land-owners, motivated by higher gains, might prefer to cultivate their lands themselves. Thus, the tenurial system was not only inequitable, but also not conducive to the adoption of new cultivation techniques. Knowing that about 30 percent of the farmers were tenants in 1978 and that land is of critical importance for explaining variations in rural incomes, any attempt to reduce poverty and income inequality cannot be separated from the need for land distribution and tenancy reforms.

\section{Labour Force Utilisation}

In the absence of recent population census results, any estimates of the labour force are necessarily speculative. The ILO Mission put it at 4,528,000 persons in 1975-1976, which should be regarded only as an order of magnitude. It also estimated the size of employment at $4,232,000$ persons. Table 1 shows that the greatest contribution to employment is made by agriculture and allied rural activities. The share of mining, handicrafts and industry is limited to 15 percent of the total and, even within this group, industry represents only 3.9 percent.

It is clear from the above that any strategy to be pursued should, along with raising workers' productivity and alleviating poverty and income inequality, especially in rural areas, attempt to face the challenge of creating new jobs through a gradual modernisation and industrialisation of the economy. This will imply devising an appropriate rural-urban strategy, with a particular stress on rural development as well as on upgrading informal activities and expanding rapidly the industrial sector.

The strategy should also include adequate education, training and labour market policies to deal with structural weaknesses in the labour force, such as shortages

${ }^{6}$ While owner-operators cultivate their land directly, eventually supplementing their family labour with hired manpower and bearing all costs of production, share-croppers are tenants paying for land use 50 percent of their gross output and bearing all production costs, except seeds, and buzgars are semi-tenants only providing labour and receiving about 20 percent of their gross output. See [4].

$$
{ }^{7} \text { See [7]. }
$$

of technicians, insufficient training and experience levels among some categories of workers, lack of equality in educational opportunities, frequent mismatch between occupations held and the qualifications of their incumbents, surpluses of secondary school graduates and imbalances in the system of incentives. Finally, to become more operational, the strategy gains to be complemented by several reforms in development planning and administration. We now come to the details of such a strategy.

\section{A STRATEGY FOR DEVELOPMENT}

\section{Rural Development}

Taking into account Afghanistan's topography, arid climate, scarcity of wate for irrigation and the fact that about four-fifths of its total population depend for their livelihood on agriculture and other rural activities, the ILO Mission concluded that the major emphasis of the employment strategy should be on rural development Since the employment problem in rural areas is essentially one of low productivity, mainly because of inadequate access of the poor households to rural resources water, land, agricultural inputs (like seeds, fertilisers and pesticides), tools and equip ments, physical and social infrastructures, credit and other institutional facilities, the Mission recommended that rural development efforts should aim at raising the poor's capability to earn more, not only through the development of such resources but also through improvements in their accessibility. This will notably mean increased allocations in the national plans for agriculture and other allied activities. Hereunder are the main components of the rural strategy proposed by the Mission.

Of all the factors determining productivity and the degree of labour intensity, water is probably the most important, since without it none of the other inputs could be used. As water is a scarce resource, and its distribution is uneven (riche farmers near the head of the canal system indulge in overuse, while smaller farmers downstream are denied their proper share), increased employment and equity will depend on bringing water to shortage areas as well as on utilising the existing supply more equitably. In particular, the time appears to have come to devote more attention to minor irrigation works, improve existing irrigation systems, regulate water rights and devise a more democratic procedure for electing the Mirab, who is responsible for supervising water distribution.

Increasing the demand for labour will also involve adopting the most appropriate technologies, as well as improving cropping patterns and expanding rural non agricultural activities. There are two alternative technologies currently available for agricultural development: the bio-chemical, or intensive cultivation through irrigation, improved seeds, fertilisers, pesticides, etc; and the mechanical or extensive cultivation with equipments of various kinds. In a country like Afghanistan where cultivable land and capital are scarce and labour is abundant, the use of bio-chemica inputs, particularly treated seeds and fertilisers, should be further widened and made 
accessible to small farmers, in view of their greater contribution to employment. On the other hand, it may be desirable to introduce tractors or other mechanical devices when further application of intensive cultivation techniques is obstructed by labour shortages or inadequacy of animal power.

As to cropping patterns, in the light of water requirements and of the possibilities opened up by the introduction of new cultivation techniques, the ILO Mission recommended double-cropping: wheat-rice or wheat-maize mixes, or combinations with leguminous crops (lentils, alfalfa, clover, etc.). Still, in order to increase output and employment, other crops that could be considered for expansion are grapes. Such improved patterns, as well as the desirable self-sufficiency in wheat, could be greatly encouraged by ensuring price stability for wheat. This could be achieved through the establishment of a strategic buffer reserve, based mainly on increased domestic production and storage, buying up wheat surpluses to maintain prices in good years and selling to lower prices in shortage years. Such a reserve would also act as a food security measure against extreme weather fluctuations.

A final tactic to augment rural employment and incomes should consist of expanding rural non-agricultural activities. Particular attention should be devoted to livestock development, including better information on the grazing potential, alternative fodder crops and the water points' spacing system and improved facilities to the nomads. Emphasis should also be given to strengthening the rural public works programme, including its integration into the overall rural development strategy. Such efforts could also raise the overall productivity in rural areas through roads and better access to markets and inputs, irrigation and energy infrastructures and improved community facilities such as drinking water, schools and health centres. They should be preceded by structural local reforms which assure that such projects do not enhance inequality.

Indeed, as critical as land development measures (e.g. afforestation, soil research, etc.) are land and tenancy reforms. Because of higher output and labour input per hectare by the smaller farmer, land redistribution is essential not only for greater equity - but also to achieve a more efficient use of rural resources. An effective land reform should overcome the handicaps which have prevented the effectiveness of the 1975 Land Reform: the high ceiling for irrigated land; the ceiling applied to individual instead of family ownership, which provided for inter-family transfers within the two-years grace period left for the disposal of excess land; the absence of proper land records and a slow progress in the cadastral survey. Land redistribution should be complemented by tenancy reform, along the following lines: (i) security of tenancy by law, to guarantee to a tenant land which he has cultivated for years; (ii) registration of tenancy arrangements, to prevent landlords from misrepresenting them as landlord/servant relationships; (iii) standardisation of the share-croppers' part of the produce, preventing its reduction as land becomes more productive; and (iv) full rights of participation by tenants in cooperatives and other rural development programmes. Such reforms would also require the building up of social support and rendering the rural power structure less unequal.
Social support could considerably increase through the development of rural institutions. In particular, agricultural extension services should be made more effective, decentralising to the extension agents day-to-day field decisions, encouraging the active participation of small farmers in cooperatives and coordinating with other agencies the appropriate delivery of inputs. As to credit facilities, the Agricultural Development Bank's security requirements for lending should be relaxed for small farmers and share-croppers, an example being the extension of second loans where non-payment of first loans was due to natural catastrophe. Finally, the rural health system should be strengthened, particularly by laying emphasis on children under 5 and mothers, by upgrading local midwives and by expanding the village health workers' programme focused on early detection and treatment of key diseases, health education and advice on nutrition and sanitation.

\section{The Urban Informal Sector}

In urban areas, the employment problem is linked to the low productivity of the informal or unorganised sector, to the weakness of the modern sector, and to inadequate training facilities and incentives. Therefore, the urban strategy recommended by the ILO Mission consisted of upgrading the informal sector, expanding the industrial sector and proposing appropriate adjustments in training and labour market policies. We shall analyse the policies proposed in that order.

The informal sector consists of self-employed household enterprises (sometimes with hired labour), engaged in a range of activities (e.g. handicrafts, some artisan industries, petty trade and certain services like transport and repair), and generally presenting the following characteristics: work - and income-sharing between household members, meagre internal non-labour resources and limited access to external resources (e.g. markets, credit, extension and training facilities). These characteristics explain the informal households' low-earning capability as well as their relative poverty: although a good part of them do not fall below the absolute poverty line defined above, a majority of the urban poor are likely to belong to these households. As in the case of rural households, the ILO Mission viewed their development mainly through better access to resources.

Firstly, the informal households' access to markets should be furthered, especially through increased links with modern industries. A particular possibility would be to encourage the sub-contracting by large industries to small workshops of the production of spare parts, also using the informal enterprises' services for small equipments, repair and maintenance. Secondly, credit facilities should be made available to such enterprises, in particular through the creation of a small business finance corporation. In the case of carpet and rug weavers, less dependence on wholesalers could be effected through improved access to credit via cooperatives, which would deal directly with banks for obtaining credit to their members and with wholesalers for securing better prices. Thirdly, extension, technical and management training programmes should be directed at informal enterprises in order to improve 
techniques and skills at their disposal and hence the quality of their products. Finally, to design an effective upgrading programme for such enterprises, more information should be sought on their structures in terms of products, investment, employment, incomes, markets and sources of finance. In view of its importance, special information could be elicited on the women's role in informal activities, the difficulties which they confront and the facilities which would make it more effective.

\section{Industrialisation}

Although the industrial sector is still small, its rapid development is essential for complementing the rural development strategy outlined above. Indeed, it could reduce the economy's excessive dependence on agriculture, widen its technological base and help it to achieve greater self-sufficiency, thus contributing to an increase in employment and incomes together with an improvement in the country's balance of payments. In the context of Afghanistan, the industrial strategy to be pursued should be closely linked with agricultural development: on the one hand, industries with the greatest growth potential are dependent on agriculture for raw materials as well as markets and the expansion of the rural purchasing power conditions industrial growth; on the other, agricultural development could be stimulated and rural consumption levels raised through the greater availability of locally produced industrial goods, tools and equipments.

In the light of the above, the industrial strategy recommended by the ILO Mission included (i) upgrading informal handicrafts and artisan industries (as described above), (ii) expanding existing modern industries based mainly on domestic raw materials and markets, and (iii) establishing selected new industries, including export-oriented ones. Initially, industrial growth would be mainly import-substituting, but with time it would export on a larger scale its fully manufactured products. As regards import-substitution prospects, it seems that there is substantial scope for expansion in the present 'policy of substituting imports of consumer goods and intermediates such as fertilisers and cement. In particular, the rapid increase of the demand for fertilisers calls for a further development of the domestic capacity in order to contain imports of that product. With respect to exports, Afghanistan's comparative advantage in its agricultural and animal-based products, as well as favourable trends in world prices for its major export commodities (cotton, fruits, nuts, etc.) suggest further processing and export possibilities.

Based on this broad strategy, the ILO Mission examined various feasible industries to determine products most suitable for expansion or new development. Judgements were based on criteria of availability of raw materials, demand, cost, employment and income implications for low-income groups and the desirable gradual build-up of greater technological self-reliance. Both the products and the appropriate industrial organisation for different products were distinguished, including the three existing forms of organisation: public, private formal and informal. It

was suggested that the public sector include the following large-scale industries: (i) cotton ginning, sugar, textiles, oil processing, fertilisers and cement (all existing) and (ii) tyres, inner tubes, textile machinery, nuts and bolts (all new). As to industries suggested for the private formal and informal sectors, they are listed in Table 2.

Table 2

Industries Suggested by the ILO Mission for the Private Formal and Informal Sectors, 1978

Private Formal Sector,

Small and Medium Scale

Informal Sector

(a) Products already produced

Pharmaceuticals

Plastic or rubber footwear

Plastic utensils

Fruit and nut packing and processing

Metal utensils

Joinery products

Carpentry products

Hand tools

Leather and footwear

Carpets

Handicrafts of leather or cloth

Hand-woven cotton and textiles Soap

\section{(b) New Products}

Soap

Matches

Cigarettes

Bicycle tyres and inner tubes

China teapots and plates, etc.

Safety razors

Nails

Improved agricultural implements and simple-powered equipment Spare parts for equipment

Pumps

Mantle kerosene lamps

Sewing machines

Automotive batteries

Bicycles

Radio/Tape-recorders

Locks and keys
Glassware

Vegetable packing and processing

Matches

Hemp yarn

China teapots, plates, etc. Candles

Nails

Improved hand tools

Spare parts for equipment Simple kerosene lamps

Wider range of metal utensils (teapots etc.)

Soil/cement bricks

Silk spinning and weaving

Locks and keys 
As regards the technology to be adopted, it will largely be determined by the form of industrial organisation which is selected, as well as by the nature of the product and its scale of operation. In addition, the ILO Mission pleaded for the continued utilisation of the not overly automated technology already in use, since it saves foreign exchange and capital, thereby enabling more industrial projects to be taken up, and since further automation would reduce available jobs, undercutting the scope for domestic market expansion by decreasing effective demand. It also suggested turning to other developing countries for importing technology and equipment for small-scale industries. Finally, parallel to technological improvements, it recommended a general programme of industrial upgrading, including considerable extension in training, credit and marketing facilities.

\section{Education, Training and Labour Market Policies}

The Mission's review of manpower supply and demand in Afghanistan concluded at structural imbalances in labour force utilisation, consisting of shortages in the skills required for implementing the above strategy and of inadequate training levels coexisting with surpluses of secondary school graduates and cases of misallocation and underutilisation of human resources. It stressed the need for appropriate manpower development and utilisation policies to adjust manpower supply to the requirements of the economy and at the same time equalise employment and training opportunities. This would imply the provision of more adequate education and training facilities. The design of such facilities should itself be accompanied by the promotion of an incentive system encouraging the search and utilisation of the required skills.

The education and training strategy recommended by the ILO Mission included the following priorities:

(1) In view of the emphasis placed on rural development, training for the development of rural areas, especially the training of agricultural and small industry extension agents and of village health workers, should receive high priority in the educational strategy;

(2) Additional resources for primary education should preferably flow to the rural areas, since literacy could facilitate the assimilation of the reforms advocated by the Mission;

(3) The efficiency of secondary education should be increased, reorienting technical/vocational schools towards specialised courses more adapted to manpower needs, increasing on-the-job training as compared with formal schooling and strengthening equity in secondary admissions;

(4) The output of higher education should be adjusted to the requirements for high-level manpower mainly through a more judicious use of existing facilities, again taking into account the need for equity in admissions;
(5) Because the role of women is critical to development, female participation in education should be encouraged at all levels, particularly in primary and village development education, special care being given to the training of rural female teachers;

(6) Teacher-education needs should be reformulated for consistency with the above manpower requirements, in particular the supply of primary teachers;

(7) Access to mass-media (e.g. newspapers, the radio) and to developmentoriented educational materials (e.g. instructional booklets) should be expanded; and

(8) Finally, efficient planning of the education and training system requires better manpower information than is now available, including supplementing the data of the national population census (on labour force, employment, occupation, education, etc.) by more detailed household, establishment and graduate follow-up surveys.

To overcome the misallocation and underutilisation of human resources, and to attract the required manpower into particular industries, occupations and regions, appropriate labour market policies should be devised. In particular, wage/salary levels should be reviewed, in order to correct inter-sectoral, inter-skill and interregional income differentials (e.g. higher wages in the private sector, except for permanent unskilled workers; much higher salaries of administrative workers as compared to professional workers in the civil service; in this same service and for the same job, superior ranks of Kabul workers as compared to those in State enterprises, provincial Governments, etc.). In the light of changes in productivity, relative wages and the cost of living, there seems to be a case for establishing a tripartite committee, consisting of representatives of Government, workers and employers, to make periodic recommendations concerning minimum wages. In addition, consideration might be given to raising the minimum wage from 900 to 1,000 Afghanis.

More generally speaking, labour legislation and industrial relations should be strengthened. Thus, careful attention should be given to the examination and adoption of the draft Labour Code prepared with the ILO's assistance. On the other hand, the importance of trade unions in improving working conditions has been recognised. All this will no doubt contribute to better manpower utilisation.

\section{Development Planning and Administration}

Finally, the implementation of the above strategy requires a coherent policy framework. Up to 1978 , development plans lacked a clear strategy, tending to be limited to enumerations of individual projects. The set of policies proposed by the ILO Mission could help in better focusing planning activities, the latter starting from that basic frame to translate policies into more specific programmes, projects and measures. For that purpose, the ILO Mission made some suggestions aimed at strengthening the planning mechanism. 
Thus, at the central level, the project evaluation capacity of the Ministry of Planning should be increased and a body established for ensuring inter-ministerial coordination in the formulation and implementation of plans. At the regional level, planning cells could be set up in each Governor's office to identify projects and monitor their implementation, and area plans prepared for major irrigation projects At a more aggregate level, a comprehensive data base should be developed, including a comprehensive household survey to provide detailed information on household characteristics in terms of employment, unemployment or under-employment, occupation and education status, levels and sources of income, ownership of productive assets, levels and patterns of consumption expenditures, savings, loans and their use, etc. Such a survey would provide not only a better knowledge of labour force utilisation, income distribution and.the satisfaction of basic needs, but also a profile of the poor, the primary group in any development strategy, in terms of who they are, where they are located and what the reasons for their poverty are.

If development plans are to succeed, it is also necessary to gear the Administration to development tasks. This will imply several administrative reforms. To begin with, assignments should preferably take place within the framework of well-conceived structures and programmes, including clear definitions of jobs to be performed. Besides, the recruitment activities of the Administrative Reform Department should be re-appraised with a view to improving the registration of schoolleavers, the notification of actual or anticipated vacancies and the coordination and reporting of placements.

In addition, in order to encourage the right motivations, existing procedures for transfers and promotion should be improved and a merit-recognition system developed. Special incentives could be provided for assignments in the provinces. Salary levels and structures should be revised in the light of changes in the costs of living, relative wages and skill requirements. Finally, for the sake of efficiency, there should be a greater delegation of authority and responsibility at different levels of the administrative system, as well as a more functional approach to work by the departments responsible for personnel management and general service operations. It is encouraging to note that the new Government has already given evidence of its will to effect the desirable changes in development planning and administration.

\section{CONCLUSION}

This article has addressed itself to the delicate problem of evolving a development and employment strategy for a country still in early stages of development and with its socio-economic structures characterised by (i) a strong predominance of agricultural/rural activities, implying low productivity levels and a high degree of poverty and income inequality, itself linked to unequal land distribution and inequitable tenancy practices; (ii) a very small industrial sector, supported by weak infrastructures, although with a considerable development potential, due to the country's mineral resources; (iii) severe limitations in its trade and capital patterns; and (iv) manpower bottlenecks coexisting with problems of misallocation and underutilisation of the labour force.

To modernise these structures and thus to help the Government in achieving fuller and more productive employment, in reducing poverty and income inequality and in satisfying the basic needs of the mass of the population, the ILO Mission has recommended a four-pronged attack:

(1) A particular stress on rural development aiming at strengthening existing activities and promoting rural workers' productivity and equal access to resources through the following reforms: (i) better cultivation patterns and techniques using improved inputs; (ii) expansion of rural nonagricultural activities; (iii) development of rural institutions (extension service, cooperatives, credit, etc.) and physical and social infrastructures (irrigation channels, transportation systems, schools, health centres, etc.); and last, but not the least, (iv) land and tenancy reforms accompanied by appropriate changes in the rural power structure;

(2) An urban strategy aiming at increasing the employment and income potential of the informal sector through better access to resources (markets, credit, extension and training facilities), and stimulating rapid development of the industrial sector by expanding modern, mainly import-substituting, industries, by establishing selected new industries, including export-oriented products, and by using appropriate technologies and incentives;

(3) To secure the success of the above rural/urban strategy, appropriate education, training and labour market policies satisfying the objectives of meeting skill requirements, equalising educational opportunities and providing the required incentives; and, finally,

(4) Reforms in development planning and administration to put into operation the above strategy with stronger chances of success.

It is hoped that the proposed strategy will not only assist the Government of Afghanistan in overcoming its development constraints, but will also provide a policy framework for other countries in similar stages of development.

\section{REFERENCES}

1. Afghanistan. Ministry of Planning. Survey of Progress: 1968/1969. Kabul. 1969.

2. Afghanistan. Ministry of Planning. Survey of Progress: 1970/1971. Kabul. 1971.

3. Afghanistan. Ministry of Planning. Survey of Progress: 1971/1972. 
4. ILACO. Small-Scale Irrigation Projects. Arnhem. 1971.

5. ILO. A Development and Employment Strategy for Afghanistan. Geneva. (Forthcoming)

6. UN/OTC Town Planning Team. Socio-economic Surveys. Kabul: Town Planning Authority. 1970.

7. World Bank. Appraisal of Khanabad II Irrigation Projects. Washington, D.C. 1978. 